\section{Field Testing Peach Rootstocks for Resistance to Armillaria Root Rot}

\author{
T.G. Beckman ${ }^{1}$ \\ U.S. Department of Agriculture, Agricultural Research Service, Southeastern \\ Fruit and Tree Nut Research Laboratory, 21 Dunbar Road, Byron, GA 31008
}

P.L. Pusey ${ }^{2}$

U.S. Department of Agriculture, Agricultural Research Service, Tree Fruit Research Laboratory, 1104 N. Western Avenue, Wenatchee, WA 98801

Additional index words. Prunus persica, plum, Prunus hybrid, Armillaria tabescens, Quercus sp., disease resistance, peach tree short life, PTSL, breeding

\begin{abstract}
Armillaria root rot is the second leading cause of peach tree mortality (after peach tree short life) in the southeastern United States. Currently, there are no commercially available rootstocks for peach with proven resistance to this pathogen in the United States. Since 1983, we have been screening rootstock candidates for resistance to Armillaria utilizing naturally infected field sites. Inoculation of peach [Prunus persica (L.) Batsch], plum (P. cerasifera J.F. Ehrh., P. munsoniana F.W. Wight \& Hedr., P. salicina Lindl. or $P$. angustifolia Marsh.) $X$ peach and plum $x$ plum hybrid rootstocks with infected plant tissue (such as acorns, Quercus sp.) prior to planting has provided a significantly increased infection and mortality of candidate rootstock lines in comparison with sole reliance on natural inoculum on an infested site.
\end{abstract}

The principal causes of premature tree mortality in the peach growing areas of the southeastern United States are peach tree short life (PTSL), responsible for $\approx 50 \%$ of tree deaths annually (Miller, 1994), and Armillaria root rot (ARR). The latter disease is estimated to be responsible for $35 \%$ of annual tree losses with an estimated lifetime production value (value of lost crops through an expected 15 year lifespan) of \$5-6 million (Miller, 1994).

The peach trees in these areas are propagated almost entirely on peach seedling rootstocks, typically 'Lovell', 'Nemaguard', and, more recently, 'Guardian' ${ }^{\circledR}$ Brand BY5209. 'Lovell' has been the most important rootstock for the past 20-30 years because of its demonstrated superior tolerance to PTSL (particularly when compared with 'Nemaguard'). 'Nemaguard' has been limited primarily to those areas infested with root-knot nematodes (Meloidogyne sp.) as 'Lovell' is not resistant to these pests. The use of 'Nemaguard' on PTSL-prone sites has been strongly discouraged. 'Guardian’ ${ }^{\circledR}$, released cooperatively by

\footnotetext{
Received for publication 29 Oct. 1999. Accepted for publication 25 Apr. 2000. Research was conducted at Southeastern Fruit and Tree Nut Research Laboratory, Byron, Ga. Use of trade names does not imply endorsement of the products named nor criticism of similar ones not named. We gratefully acknowledge the generous donation of sawtooth oak acorns by the U.S. Dept. of Agriculture, Soil Conservation Service, Quicksand Plant Materials Center in Quicksand, Ky., and also thank Raymon Pate and Kathy Halat for their suggestions and assistance in this research. The cost of publishing this paper was defrayed in part by the payment of page charges. Under postal regulations, this paper therefore must be hereby marked advertisement solely to indicate this fact. 'ResearchHorticulturist.E-mail address:tbeckman@ saa.ars.usda.gov

${ }^{2}$ Research Pathologist.
}

the U.S. Dept. of Agriculture (USDA) and Clemson Univ. in 1993 (Okie et al., 1994a), is rapidly displacing both 'Lovell' and 'Nemaguard'. 'Guardian' ${ }^{\circledR}$ is clearly more resistant to PTSL than is 'Lovell'. In addition, 'Guardian' ${ }^{\circledR}$, unlike 'Lovell', appears to have root-knot nematode resistance comparable to that of 'Nemaguard'. Like most peach seedling rootstocks, 'Lovell', 'Nemaguard', and 'Guardian' ${ }^{\circledR}$ are all susceptible to Armillaria root rot. In the southeastern United States, Armillaria tabescens (Scop.:Fr) Dennis et al. appears to be the most commonly encountered species attacking fruit trees. However, A. mellea (Vahl.:Fr) P.Kumm. has also been reported (Bertrand, 1989).

In an early cooperative trial, designed to look for resistance to PTSL, only $10 \%$ of the starting population was still alive at the Byron location after 9 years (Okie et al., 1994b). About $50 \%$ of the trees had died from PTSL, $35 \%$ from ARR, and 5\% from all other causes combined. At the conclusion of the experiment, seedlings of 'B594520-9' (which are the source of 'Guardian' ${ }^{\circledR}$ ) had suffered significantly fewer losses to ARR than had 'Nemaguard' (Beckman, et al., 1998). Nevertheless, 'Lovell', 'Nemaguard', and 'B5945209' all had unacceptably high losses to ARR. As a screening technique, trials of this type utilizing naturally occurring inoculum on infested sites are obviously inefficient. In the absence of any practical alternatives, however, we have utilized this approach as the backbone of our initial efforts to develop ARR resistant rootstocks.

Attempts to boost infection of test subjects by incorporating Armillaria-infested bark in the tree row prior to planting failed to increase infection and mortality compared to that achieved with naturally occurring inoculum on an infested site (Pusey, personal communication). The attachment of infected pieces of peach bark directly to the rootstock shank of test subjects prior to planting was equally ineffective (Beckman, 1998). We observed that many of the Armillaria-infested pieces of bark used in our trials had no discernible mycelium present when reexamined after 1 year in the soil. Clearly, a more "durable" inoculum source was needed. Planting in close proximity to stumps of Armillaria-killed trees served well in this regard, providing a marked increase in infection and mortality of peach seedling rootstocks (Beckman, 1998), but this technique is clearly not practical for largescale field screening.

We have experimented with several other plant tissues: small diameter peach branches, pecans [Caryaillinoensis (Wangenh.)C. Koch] and acorns of several species of oak (Quercus $\mathrm{sp}$.). The purpose of this paper is to report the results of our efforts to develop improved methodologies for evaluating ARR resistance in the field.

\section{Materials and Methods}

Site. In 1994, this trial was established at the USDA laboratory at Byron, Ga., ( $\approx$ lat. $32^{\circ} 38^{\prime} \mathrm{N}$, long. $83^{\circ} 46^{\prime} \mathrm{W}$ ) on a site with a known history of Armillaria infection as demonstrated by a previous peach planting. No attempt was made to remove infected root pieces left in the soil when the peach trees were pushed out. Moreover, rows of this experiment were aligned directly over the old rows. Trees were planted $\approx 76 \mathrm{~cm}$ apart within the row with $6.1 \mathrm{~m}$ between rows. Soil type was a Norfolk loamy fine sand, a fine loamy, siliceous, thermic, typic Paleudult. No supplemental irrigation was provided.

Inoculum. Artificial inoculum treatments consisted of acorns or bark (peach and pecan) collected from living 2- or 3-year-old branches growing at the Byron location. Bark was removed from the woody cylinder with a knife, broken into finger-sized pieces (acorns were left intact), and autoclaved twice (1-2 d between sterilizations) in 2.8-L wide-mouthed flasks. Each flask held 150-200 acorns or an equivalent volume of bark. Armillaria isolates were cultured on malt extract agar until the surface of the petri dish (standard $100 \times 15 \mathrm{~mm}$ ) was completely covered (30-45 d). The contents (agar and mycelium) of two petri dishes were chopped into small pieces with a flamesterilized scalpel and added to each flask under sterile conditions in a laminar flow hood. The flask contents were mixed with a sterile rod and the mouth loosely capped with sterile aluminum foil. Flasks of bark and acorn inoculum were cultured for 8-12 weeks at room temperature until bark and acorns were thoroughly overgrown with Armillaria mycelium.

Three Armillaria isolates were utilized. All isolates were obtained from Armillaria-killed peach trees near the field test location. Based on basidiocarp morphology, all appeared to be A. tabescens. Peach bark was used in two replications and pecan bark was used in the other two. Chestnut oak (Quercus prinus L.) 
acorns were used in three replications and sawtooth oak (Quercus acutissima Carruth.) acorns were used in one. An infested bark piece $(\approx 1.5 \times 6 \mathrm{~cm})$ or acorn was attached to the rootstock shank just above the first lateral root with several wraps of Parafilm ${ }^{\circledR}$. Trees were set so that inoculum pieces were $\approx 10 \mathrm{~cm}$ below the soil surface.

Rootstocks. Five rootstock treatments were included: 'Lovell' peach seedling rootstock, 'SL0040' (a complex plum hybrid selection from our breeding program, parentage unknown, probably $P$. angustifolia $\times$ P. salicina.), 'Marianna 2624' ( $P$. cerasifera. $\times P$. munsoniana $)$, 'Ishtara' $[(P$. cerasifera $\times P$. salicina $) \times(P$. cerasifera $\times P$. persica $)]$, and 'Myran' $[(P$. cerasifera $\times P$. salicina $) \times P$. persica]. The last four rootstocks were clonally propagated as hardwood cuttings. All trees were nonbudded 1-year-old nursery stock grown on fumigated soil.

Statistical analysis. The design was a splitplot with four replications of the main plot treatments: 1) none (relying solely on natural inoculum present on site); 2) an artificially infested bark piece; or 3) an artificially infested acorn. The split-plot treatments (rootstock) were: 1) 'Lovell'; 2) 'SL0040'; 3) 'Marianna 2624'; 4) 'Ishtara'; or 5) 'Myran' with four trees per plot.

Statistical analysis was carried out by first converting survival data to percentage of mor- tality from each possible cause (ARR, PTSL, or other) for each four-tree plot and then analyzing separately by cause via GLM (SAS Institute, 1988).

\section{Results and Discussion}

There was no significant interaction between main and split-plot treatments. Hence, only main effects are presented. Through five growing seasons, inoculation with infected bark pieces did not significantly increase ARR mortality over that achieved with the natural inoculum check. However, beginning in the third growing season, inoculation with infested acorns did increase ARR mortality (Table 1). Inoculation with infested acorns achieved $48 \%$ mortality through the 4th growing season, which is greater than that achieved in 9 years using only naturally occurring inoculum in another study (Beckman, 1998). Most acorns recovered 1 year after planting still retained mycelium in internal tissue similar in appearance to that observed in acorns maintained in a sterile lab environment. Experimental design did not allow statistical comparison of the acorn or bark species utilized as inoculum media.

Rootstocks differed significantly in their susceptibility to both ARR and PTSL (Table 2). After five growing seasons, only one tree of 'SL0040' was lost to ARR and none to PTSL. Losses of 'Lovell' to ARR were
Table 1. Main effects of Armillaria inoculation method on mortality of Prunus rootstocks planted on a naturally infested field site (Byron, Ga.). ${ }^{\mathrm{z}}$

\begin{tabular}{lcccl}
\hline & \multicolumn{4}{c}{ ARR mortality (\%) } \\
\cline { 2 - 5 } Method & 1995 & 1996 & 1997 & 1998 \\
\hline Natural & 1 & $18 \mathrm{ab}^{\mathrm{y}}$ & $26 \mathrm{~b}$ & $30 \mathrm{~b}$ \\
Bark-piece & 1 & $15 \mathrm{~b}$ & $28 \mathrm{~b}$ & $36 \mathrm{ab}$ \\
Acorn & 4 & $28 \mathrm{a}$ & $48 \mathrm{a}$ & $51 \mathrm{a}$ \\
MSD & NS & 12 & 13 & 20
\end{tabular}

${ }^{\mathrm{z}}$ Trial established Spring 1994.

${ }^{\mathrm{y}}$ Mean separation within columns by minimum significant difference (MSD), Waller-Duncan K ratio test $(\mathrm{K}$ ratio $=100)$.

Table 2. Main effect of Prunus rootstock treatment on mortality due to Armillaria root rot (ARR), peach tree short life (PTSL) or other causes after five growing seasons on a naturally infested field site (Byron, Ga.).

\begin{tabular}{lcccc}
\hline & \multicolumn{4}{c}{ Mortality (\%) } \\
\cline { 2 - 5 } Rootstock & $\mathrm{n}$ & ARR & PTSL & Other \\
\hline SL0040 & 48 & $2 \mathrm{~d}^{\mathrm{y}}$ & $0 \mathrm{c}$ & $2 \mathrm{~b}$ \\
Lovell & 48 & $33 \mathrm{c}$ & $0 \mathrm{c}$ & $0 \mathrm{~b}$ \\
Myran & 47 & $35 \mathrm{bc}$ & $33 \mathrm{a}$ & $25 \mathrm{a}$ \\
Ishtara & 33 & $53 \mathrm{~b}$ & $22 \mathrm{ab}$ & $11 \mathrm{ab}$ \\
M2624 & 47 & $73 \mathrm{a}$ & $17 \mathrm{~b}$ & $4 \mathrm{~b}$ \\
MSD & --- & 18 & 16 & 18 \\
\hline
\end{tabular}

${ }^{2}$ Trial established Spring 1994. Results through Fall 1998.

y Mean separation within columns by minimum significant difference (MSD), Waller-Duncan $\mathrm{K}$ ratio test $(\mathrm{K}$ ratio $=100)$.



Fig. 1. Field inoculation of a tree with an Armillaria-infected acorns. Inset: Probing hole next to trunk to receive acorn. 
greater. All three commercial clonal rootstocks, 'Marianna 2624', 'Ishtara', and 'Myran', suffered significant losses to both ARR and PTSL. This will probably limit their use in this region. Our results are in conflict with published reports indicating that these three rootstocks have some level of field resistance to Armillaria species, probably A. mellea (Cummins, 1991; Raabe, 1979; Norton, et al., 1963). This discrepancy may reflect variation in pathogen virulence within or among species. Hence, they may not be resistant to A. tabescens. Alternatively, their tolerance may be diminished by other abiotic or biotic factors in the Southeastern United States, e.g., high temperature, low soil $\mathrm{pH}$, high humidity and soil moisture, bacterial leaf spot [Xanthomonas campestris pv. pruni (Smith) Dye], bacterial canker (Pseudomonas syringae pv. syringae van Hall), plum leaf scald (Xylella fastidiosa Wells), and ring nematode [Criconemella xenoplax (Raski) Luc \& Raski].

Encouraged by these results we have incorporated a simplified version of this inoculation technique into our large scale, highdensity field trials (Fig. 1). Shortly after plant- ing, each tree is inoculated by probing a hole $\approx 10 \mathrm{~cm}$ deep immediately adjacent to the trunk with a standard soil probe $(2.3 \mathrm{~cm}$ diameter). One infested acorn is inserted into this hole. Most will drop to the bottom of the hole. If not, they are pushed to the bottom with the soil probe. The hole is then closed with the foot. Utilizing this technique, one person can inoculate up to a thousand trees in a day.

This study demonstrates that Armillaria infection and mortality in field screens can be markedly accelerated through artificial inoculation with infected acorns. This gives us hope that we can develop commercially useful materials for use on PTSL- and Armillariainfested sites in the Southeastern United States and elsewhere.

\section{Literature Cited}

Beckman, T.G. 1998. Developing Armillaria resistant rootstocks for peach. Acta Hort. 465:219224.

Beckman, T.G., W.R. Okie, A.P. Nyczepir, P.L. Pusey, and C.C. Reilly. 1998. Relative susceptibility of peach and plum germplasm to Armillaria root rot. HortScience 33:1062-1065.
Bertrand, P. 1989. Oak root rot, p. 109-112. In: S.C. Myers (ed.). Peach production handbook. Georgia Expt. Sta. Hdbk. No. 1. Coop. Ext. Serv., Univ. of Ga., Athens.

Cummins, J.N. 1991. Register of new fruit and nut varieties. Brooks and Olmo List 35. HortScience 26:951-986.

Miller, R.W. 1994. Estimated peach tree losses 1980 to 1992 in South Carolina: Causes and economic impact, p. 121-127. Proc. 6th Stone Fruit Decline Wkshp, 26-28 Oct. 1992, Fort Valley State College, Ft. Valley, Ga.

Norton, R.A., C.J. Hansen, H.J. O'Reilly, and W.H. Hart. 1963. Rootstocks for plums and prunes. Calif. Agr. Expt. Sta. Leaflet No. 158.

Okie, W.R., T.G. Beckman, A.P. Nyczepir, G.L. Reighard, W.C. Newall, Jr., and E.I. Zehr. 1994a. BY520-9, a peach rootstock for the southeastern United States that increases scion longevity. HortScience 29:705-706.

Okie, W.R., G.L. Reighard, T.G. Beckman, A.P. Nyczepir, C.C. Reilly, E.I. Zehr, W.C. Newall, Jr., and D.W. Cain. 1994b. Field screening Prunus for longevity in the southeastern United States. HortScience 29:673-677.

Raabe, R.D. 1979. Resistance or susceptibility of certain plants to Armillaria root rot. Univ. of Calif. Leaflet No. 2591.

SAS Institute, Inc. 1988. SAS/STAT guide for personal computers. Version 6.03 ed. Cary, N.C. 